\title{
GROWTH DYNAMICS AND MORPHOLOGY OF PLANKTON GREEN ALGAE FROM BRACKISH WATERS UNDER THE INFLUENCE OF SALINITY, TEMPERATURE AND LIGHT
}

\author{
${ }^{1}$ Institute of Oceanography, Gdanisk University \\ Poland \\ and \\ 2 College of Sciences, University of Latakia \\ Syria
}

\begin{abstract}
Nine unicellular green algal species isolated from the Gulf of Gdanisk phytoplankton were studied. The species were cultured within the salinity range of $0-35 \%$ at temperatures of $5-38^{\circ} \mathrm{C}$ and at light intensity (PAR) ranging within $20-380 \mu \mathrm{E} / \mathrm{m}^{2} \mathrm{~s}$. Four species were typical of brackish water, five being freshwater plants. In terms of temperature requirements, groups of three species each belonged to high temperature, mesothermophilic, and low-temperature strains. Most species required relatively high light intensities as growth of six of them was saturated at $120 \mu \mathrm{E} / \mathrm{m}^{2}$ s。
\end{abstract}

\section{INTRODUCTION}

Every food chain in aquatic ecosystems begins with planktonic algae which are the major producers of organic matter for the community. As algae are autotrophs, they support all marine life directly or indirectly. Knowledge of biology, and particularly the autecology of phytoplanktonic species as well as information on their responses to different environmental factors is therefore of great importance (Round 1977). Identification of the basic environmental factors influencing algal growth and distribution is possible to a certain extent through in situ experiments. However, reliable data can be obtained only under controlled laboratory conditions. The combination of the abovementioned methods affords proper knowledge of phytoplankton (Fogg and Thake 1982).

Strains isolated and cultured in the laboratory do not necessarily represent the total population of species in a water body studied. However, it should be noted rela- 
tively few data point to differences between laboratory cultures and natural populations (Fogg and Thake 1982).

Ecology of planktonic algae from the Gulf of Gdansk is interesting because of the non-specific features of the physicochemical environment. The relatively low salinity and a steady influx of suspended matter, pollutants and nutrients accelerating eutrophication are the main factors which greatly affect changes in the phytoplankton species composition (Pliński et al. 1985). The Gulf of Gdańsk phytoplankton consists of marine, brackish water and freshwater species. Green algae are one of the important groups, being particularly abundant in late spring and summer.

The experiments presented were aimed at elucidating effects of the major environmental factors such as salinity, light, and temperature on growth and morphology of some unicellular green algae isolated from the Gulf of Gdańsk phytoplankton.

\section{MATERIALS AND METHODS}

The following 9 species of green algae were tested:

1. Chlorella vulgaris LA-1/685;

2. Scenedesmus armatus var. subalternans LA-6/685;

3. Scenedesmus acuminatus LA-7/586;

4. Scenedesmus acutus LA-8/487;

5. Monoraphidium contortum LA-5/587/;

6. Monoraphidium griffithii LA-4/586;

7. Oocystis submarina LA-2/682;

8. Oocystis porve LA-3/487; and

9. Stichococcus becillaris LA-9/682.

Most of those species are typical of the Gulf of Gdańsk, i.e. in some periods of the growth season they are found at all sampling sites situated in different parts of the Gulf (Pliński et al. 1985). Pure algal cultures were isolated from natukal plankton communities and belong to the Laboratory of Marine Plant Ecology collection, Gdańsk University (Latała, unpubl. manuscript).

Experiments were carried out in $300 \mathrm{~cm}^{3}$ Erlenmayer flasks, each containing $150 \mathrm{~cm}^{3}$ of the medium. The medium was prepared from the Atlantic water $(35 \%)$ or from water taken at station GN $18^{\circ} 48^{\circ} \mathrm{E}, 54^{\circ} 32^{\circ} \mathrm{N}$ ) situated in the central part of the Gulf of Gdansk. As in the F/2 medium (Guillard 1975), the water was enriched with nutrients and microelements (without metasilicate and vitamins). The batch cultures were stirred vigorously once a day. The inoculum was taken from the cultures grown at $18 \pm 1^{\circ} \mathrm{C}, 27 . \mu \mathrm{E} / \mathrm{m}^{2} \mathrm{~s}$, ard $7.35 \%$. The experimental cultures, 5 replicates each, were not pre-adapted to a new temperature, light, and salinity conditions.

The following combinations of salinity, temperature and light intensity were used: 
I. Salinity: $0 ; 2.5 ; 5 ; 7.35 ; 11.5 ; 15 ; 20 ; 25 ; 30 ;$ and $35 \%$ at $18 \pm 1^{\circ} \mathrm{C}$ and $27 \mu \mathrm{E} / \mathrm{m}^{2} \mathrm{~s}$ (PAR). Different salinities were prepared from the Atlantic water (35\%) diluted with distilled water. Tap water yielded the fresh water needeed. The cultures were illuminated with 6 fluorescent tubes (POLAMP LF, $25 \mathrm{~W}$ ) and a 16:8 L:D cycle was maintained.

II. Temperature: $5 ; 10 ; 14 ; 18 ; 22 ; 26 ; 30 ; 34 ;$ and $38 \pm 1^{\circ} \mathrm{C}$ at $7.35 \%$ ano $27 \mu \mathrm{E} / \mathrm{m}^{2} \mathrm{~s}$ (PAR). The medium was prepared from the Gulf of Gdansk water $(7.35 \%)$. The light source used consisted of 5 fluorescent tubes (POLAMP LF, $25 \mathrm{~W}$ ). The algae were incubated at a $16: 8 \mathrm{~L}: \mathrm{D}$ cycle.

III. Light intensity (PAR); 20;30;45;80;120;150;270; and $380 \mu \mathrm{E} / \mathrm{m}^{2} \mathrm{~s}$ at $18 \pm 1^{\circ} \mathrm{C}$ and $7.35 \%$. The cultures were illuminated with high-pressure sodium lamps, the light intensity being controlled with neutral filters. A 16:8 L:D cycle was used. The medium was prepared from the Gulf of Gdansk water $(7.35 \%)$.

The light intensity (PAR) measurements were carried out using an FF-01 phytophotometer (made in Poland). The cell number was determined by counting the cells in a Burker chamber. To determine cell morphology of the species examined, the mean cell size of 50 cells at the exponential growth phase was calculated. The cell volume was estimated as recommended by Edler (1979). Regression analysis was performed and correlation coefficients between the cell volume and different light intensity, temperature or salinity were calculated. Statistical significance of regression equations and correlation coefficients was tested using Student's $t$ test and the analysis of varience. All the regression equations and correlation coefficients were significant at $\alpha=0.05$.

\section{RESULTS}

To obtain detailed information on requirements of individual species, wide ranges of salinity, temperature, and light intensity were used.

Five of the species studied show the best growth in fresh water (Species 2, 3, 4, 5) or at a very low salinity of $2.5 \%$ (Species 6 ). They also exhibit low resistance to higher salinity as shown by a decrease in their growth at 15 or $20 \%$. Fig. 1 presents the growth curves for one of these species, Monoraphidium contortum. Three of the species tested (Species 1, 8 and 9) grew most luxuriantly at $7.35 \%$ (salinity typical of the Gulf of Gdansk), Stichococcus bacillaris tolerating also the wide range of salinity $(0-30 \%$ and even $35 \%$ applied. The growth curves of S. bacillaris are shown in Fig. 9. 2. Oocystis submarina (Species 7) shows the best growth at a relatively high salinity (11.5-15\%) and is tolerant of the whole range of salinity used, i.e. $0-35 \%$ (Fig. 3).

Different salinities considerably affect morphology of the green algae studied, except for Oocystis parva. An increase in cell volume with increasing salinity was 


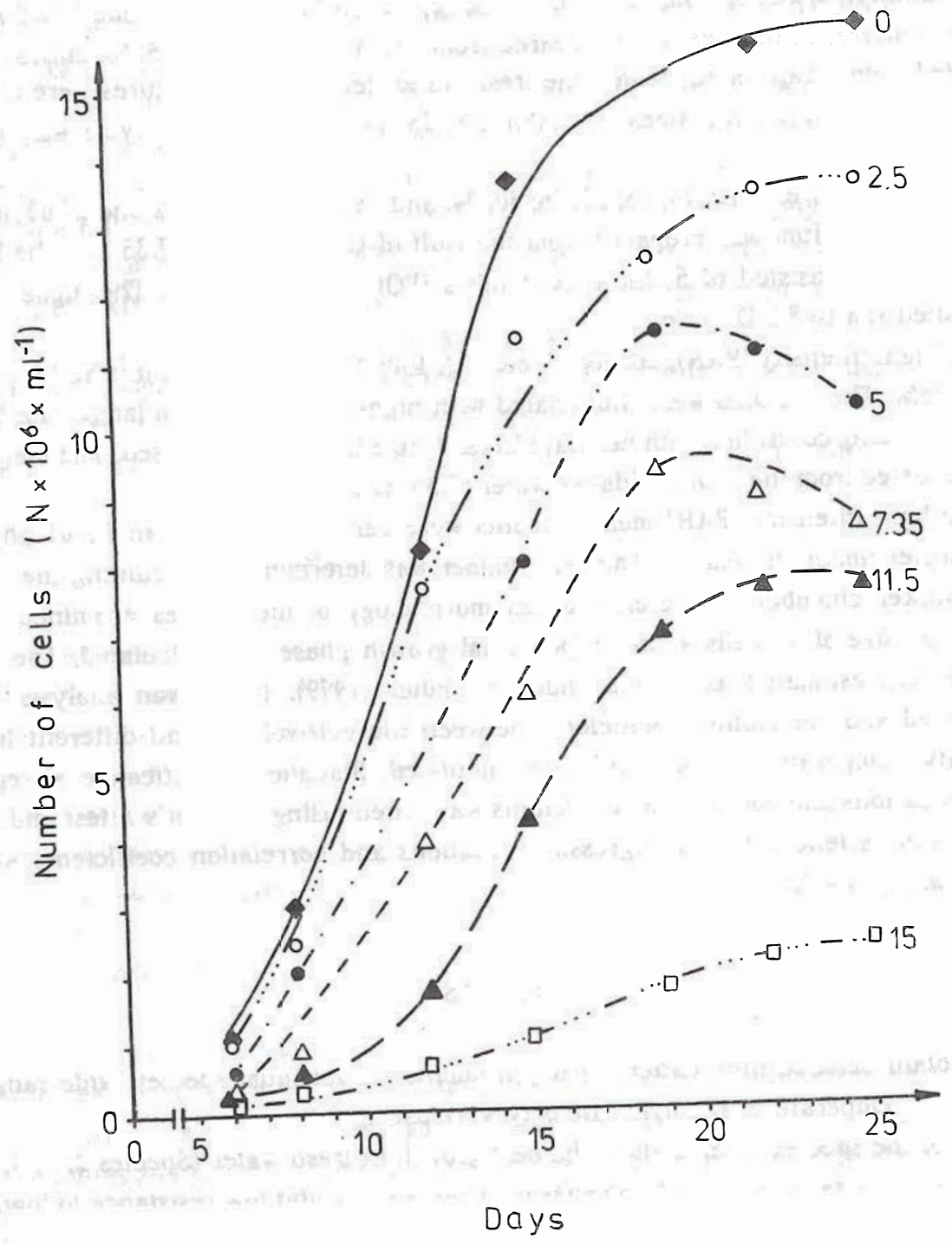

Fig. 1. Monoraphidium contortum growth curves in relation to salinity ( $\%$ ) 


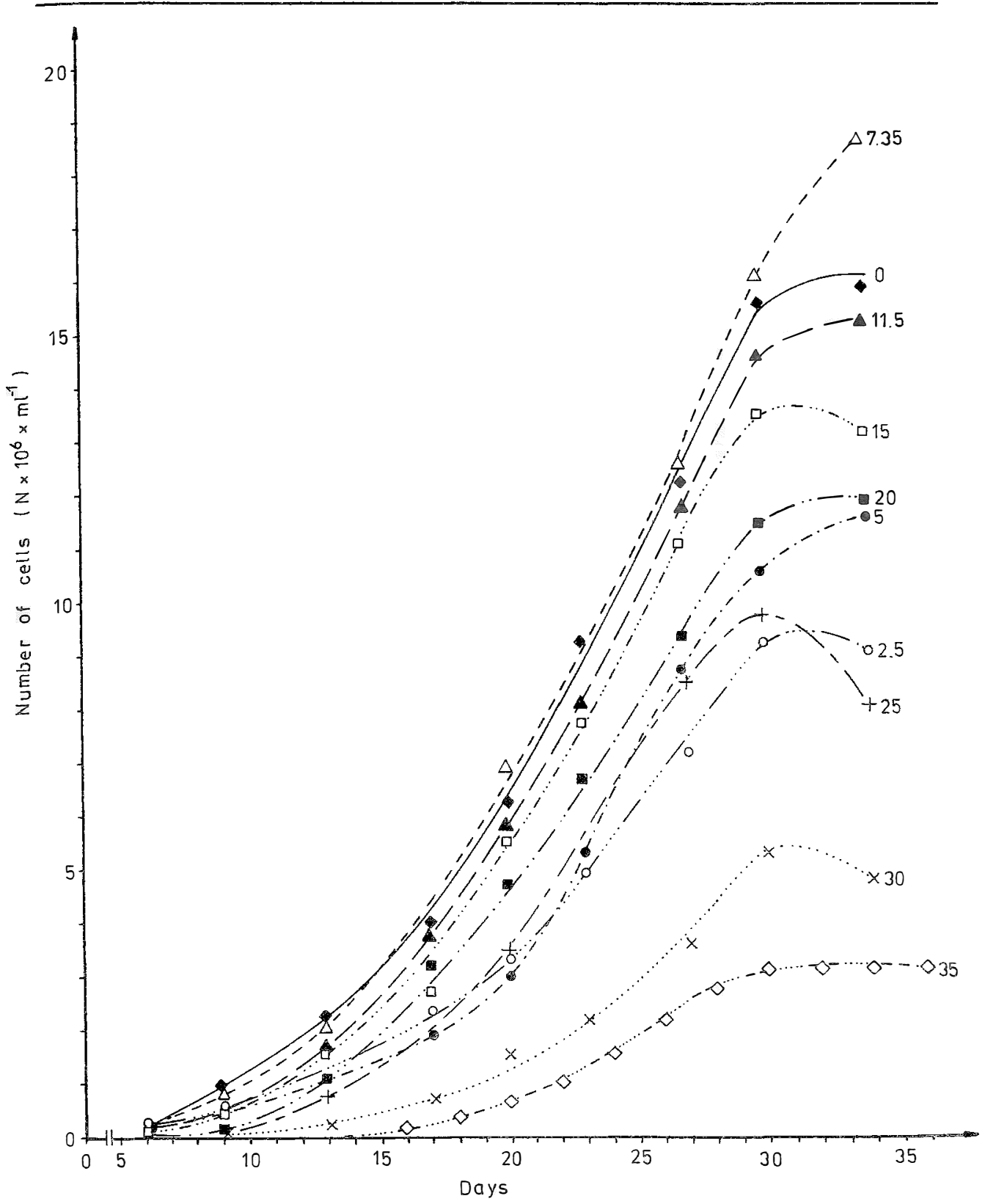

Fig. 2. Stichococcus bacillaris growth curves in relation to salinity (\%) 


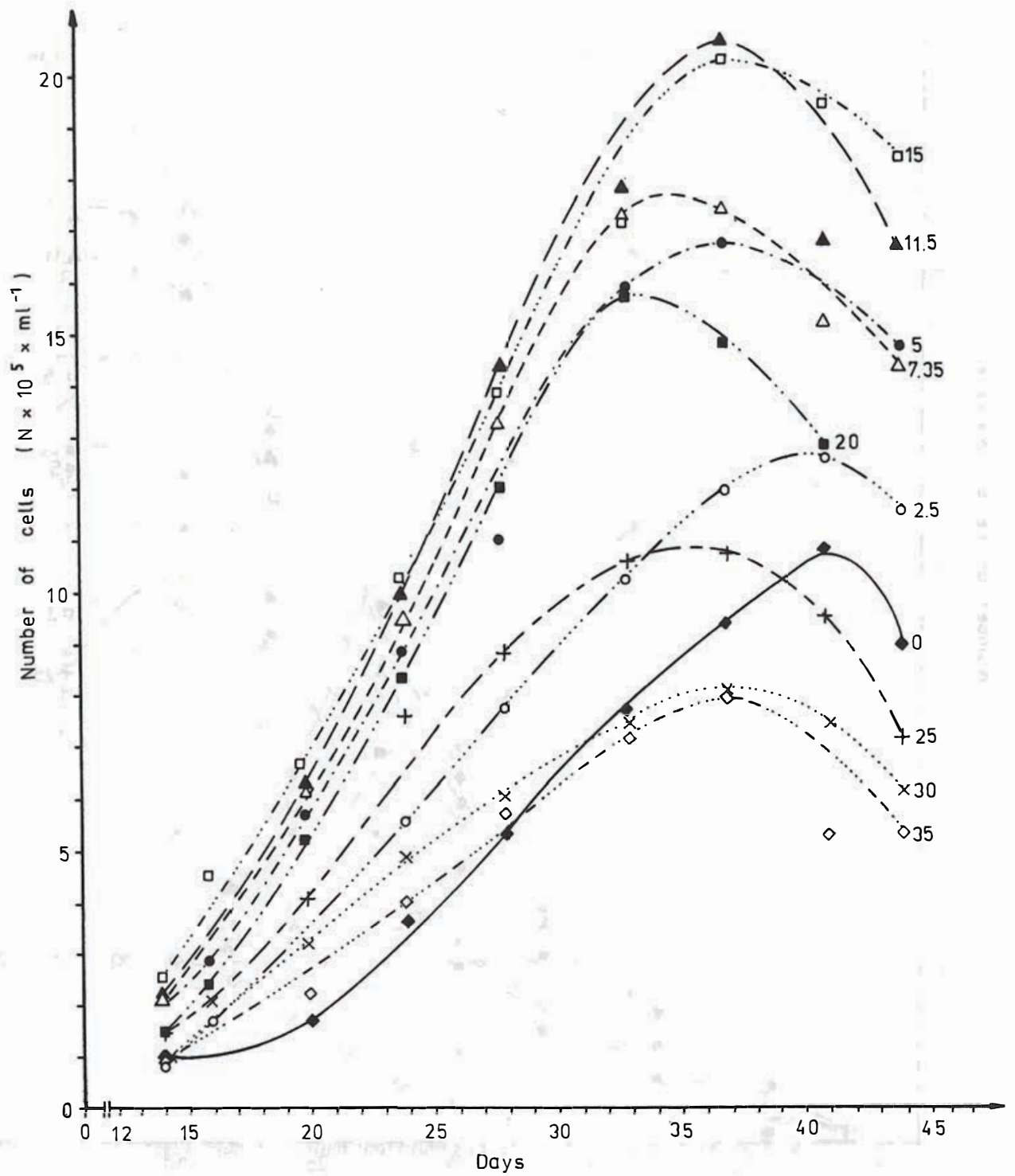

Fig. 3. Oocystis submarine growth curves in relation to salinity (\%) 




Fig. 4. The plot of regression between salinity and the cell volume of Scenedesmus armatus, together with measured yalues. Dotted lines represent confidence and prediction limits

observed. Scenedesmus armatus showed the highest correlation coefficient $(0.80)$ between the cell volume and salinity within $2.5-25 \%, R^{2}$ for this species being $64.2 \%$. Fig. 4. presents the scatter of data obtained along with the regression line. Relatively high correlation coefficients, i.e. above $0.55 \mathrm{R}>30 \%$ ), were obtained in 5 species (Species $1,3,4,5$, and 9).

Effects of temperature on growth of the green algae studied was diversified. Five species (Species 1, 2, 3, 6, and 9) grew best at high temperatures $\left(26-30^{\circ} \mathrm{C}\right)$, Scenedesmus ac uminatus yielding the most luxuriant growth even at $34^{\circ} \mathrm{C}$. Typical growth curves for Chlorella vulgaris cultures at different temperatures are presented in Fig. 5. The species mentioned exhibit a poor growth or cease growing at $5-10^{\circ} \mathrm{C}$. The remaining species examined showed an optimal growth at $18^{\circ} \mathrm{C}$ and grew also at the lowest temperature used $\left(5^{\circ} \mathrm{C}\right)$, but did not loterate the highest temperature $\left(38^{\circ} \mathrm{C}\right)$. Examples of such relationships can be found in the growth curves of Oocystis submarina presented in Fig. 6. 


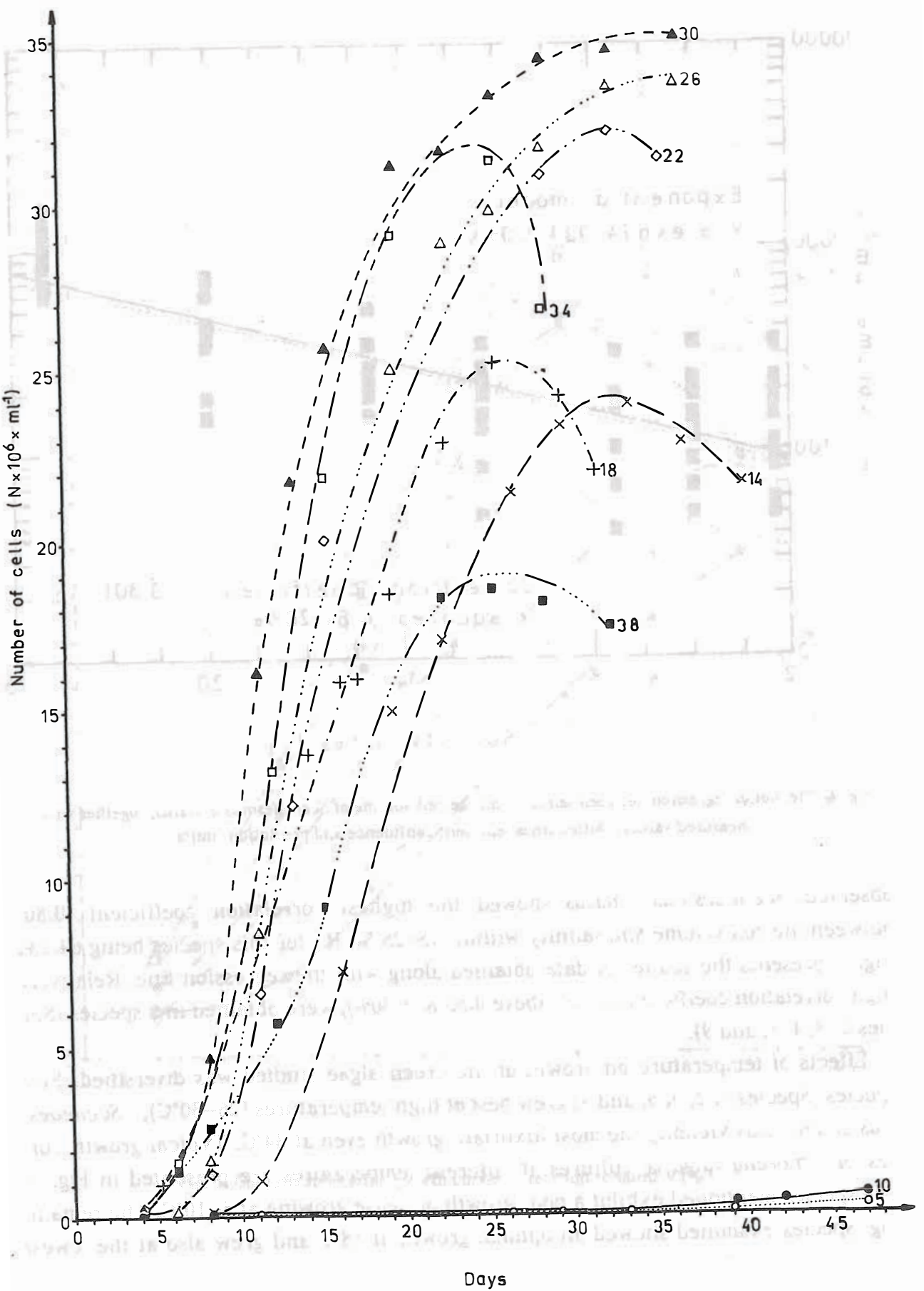

Fig. 5. Chlorello vulgaris growth curves in relation to temperature $\left({ }^{\circ} \mathrm{C}\right)$ 


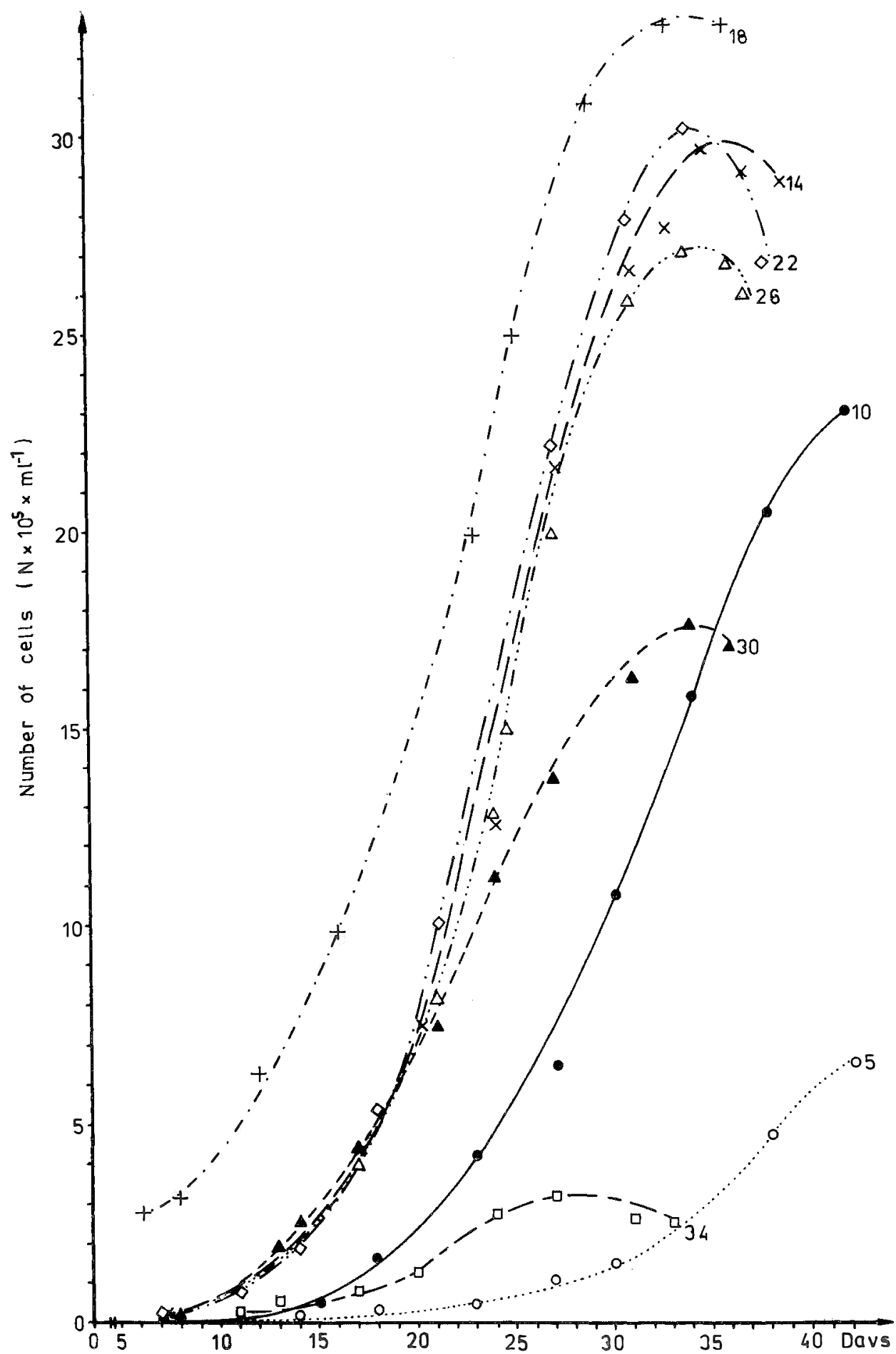

Fig. 6.Oocystis submarina growth curves in relation to temperatures $\left({ }^{\circ} \mathrm{C}\right)$ 


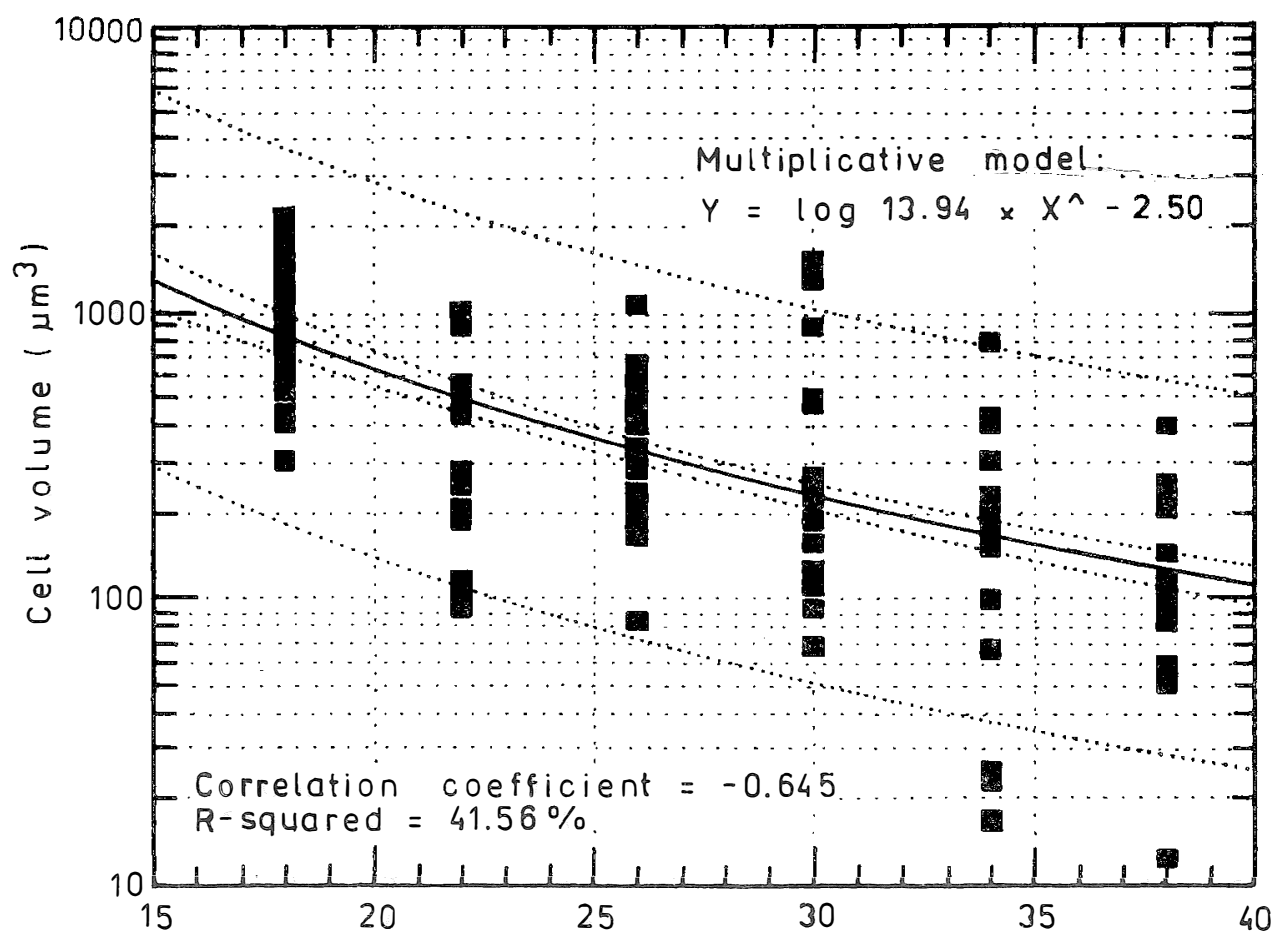

Temperature $\left({ }^{\circ} \mathrm{C}\right)$

Fig. 7. The plot of regression between temperature and the cell volume of Scenedesmus acuminatus, together with measured values. Dotted lines represent confidence and prediction limits

Except for the two Scenedesmus species, effects of ternperature on algal morphology was diverse and of a minor importance only. The cell volume of Scendesinus acuminatus decreased with termperature increasing from 18 to $38^{\circ} \mathrm{C}$. Fig. 7 presents results of the measurements together with the calculated regression values. The correlation coefficients were $r=0.65$ and $R^{2}=42 \%$. Scenedesmus armatus showed also a certain correlation between the cell volume and temperature in the range of $10-30^{\circ} \mathrm{C}$.

The algal species studied have high light requirements. Six species (Species 1, 2, 4, 5,6 , and 9) grew best at a high radiation intensity (PAR of $120 \mu \mathrm{E} / \mathrm{m}^{2} \mathrm{~s}$ ) and a $16: 8$ L:D cycle, i.e. the minimum daily quantum illumination causing growth saturation is equal to $7 \mathrm{E} / \mathrm{m}^{2} \mathrm{~s}^{\circ} \mathrm{d}$. Fig. 8 shows growth curves at different light intensities for one of the species Monoraphidium contortum. The species mentioned above grew also at the highest radiation intensity $\left(380 \mu \mathrm{E} / \mathrm{Mm}^{2} \mathrm{~s}\right)$, but their growth was rather poor. Two of the species examined (Species 3 and 8) showed the best growth at a lower light iniensity 


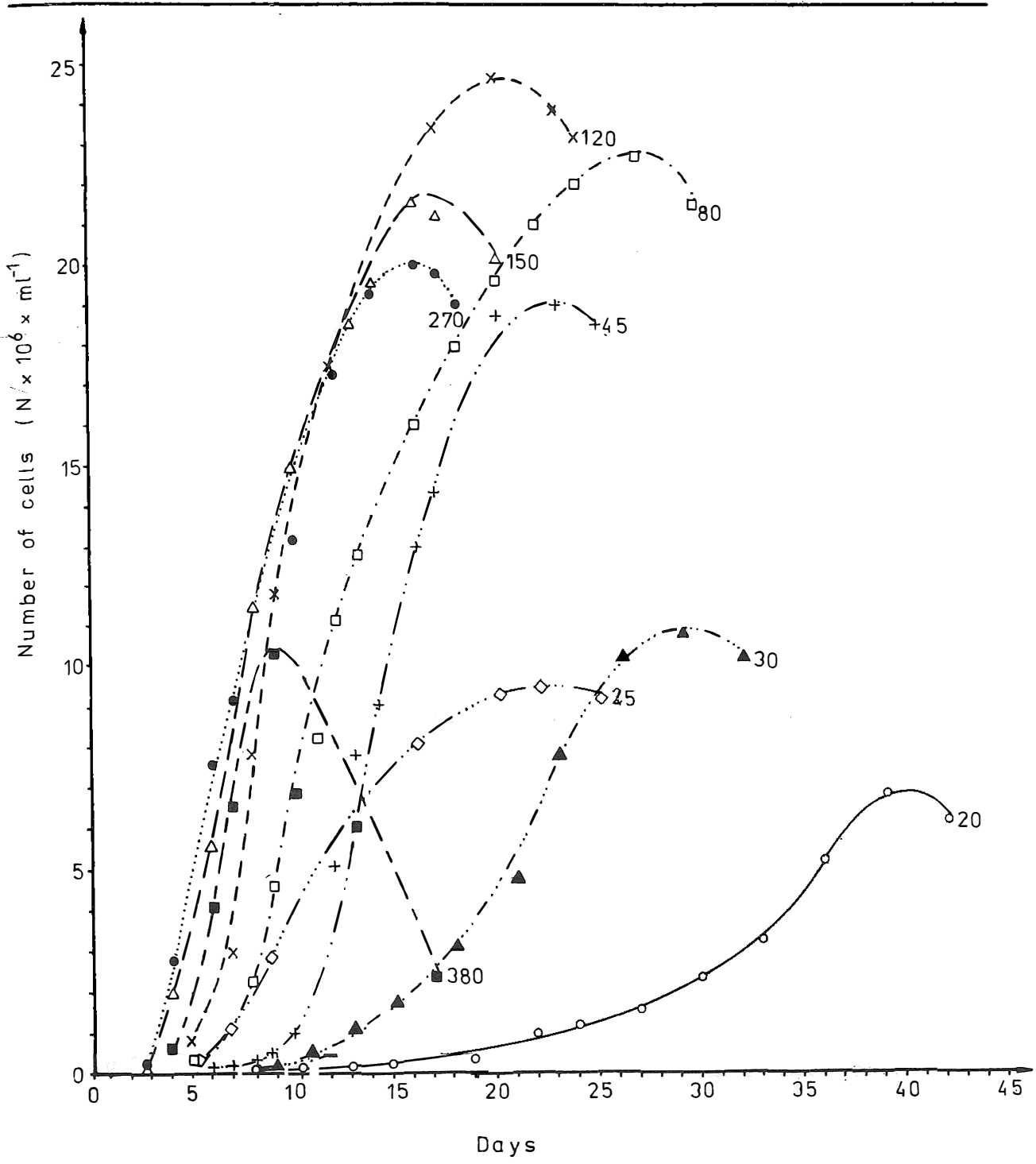

Fig. 8. Monoraphidium contortum growth curves in relation to light intensity PAR $\left(\mu \mathrm{E} / \mathrm{m}^{2} \mathrm{~s}\right)$

$\left(80 \mu \mathrm{E} / \mathrm{m}^{2}\right)$; only in Oocystis submarina (Fig. 9) was the growth most luxuriant at $45 \mu \mathrm{E} / \mathrm{m}^{2}$ s. Growth of $O$. submarina was almost completely inhibited at high light intensities $\left(270-380 \mu \mathrm{E} / \mathrm{m}^{2} \mathrm{~s}\right)$.

Different light intensities used induced no significant changes in cell morphology in four of the species (Species 3, 4, 5, and 6). On the other hand, increasing light intensity was observed to cause various changes in cell volume in other species (Species $1,2,7,8$, and 9). The highest correlation coefficients $\left(r=0.597 ; R^{2}=3.565 \%\right)$ were 


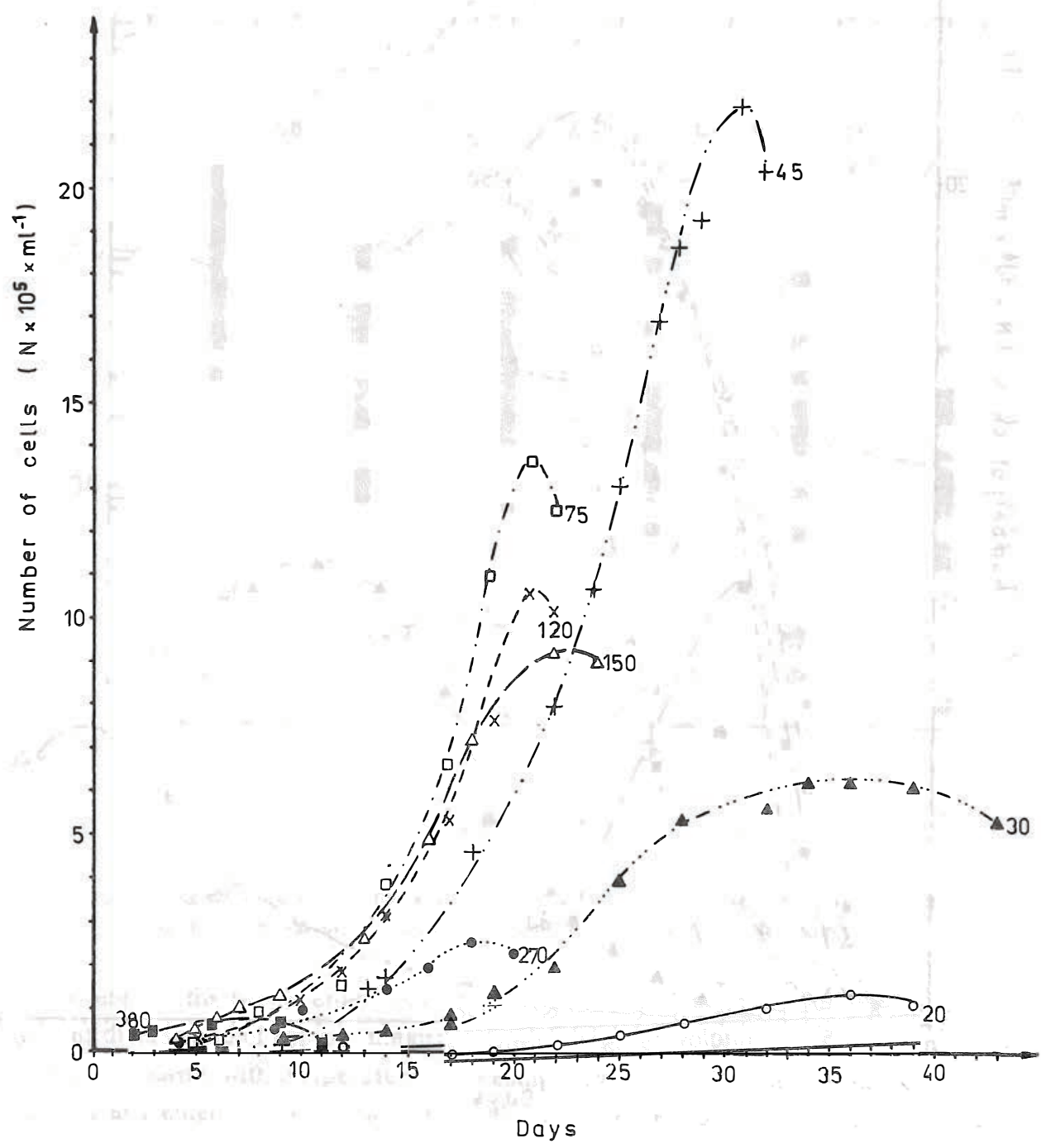

Fig. 9. Oocystis submerine growth curves in relation to light intensity PAR $\left(\mu E / m^{2} s^{-1}\right)$

recorded for Oocystis parva. Results of the measurements and the calculated regression values for the species are shown in Fig. 10. The correlation coefficients were slightly lower in the remaining 3 species. 


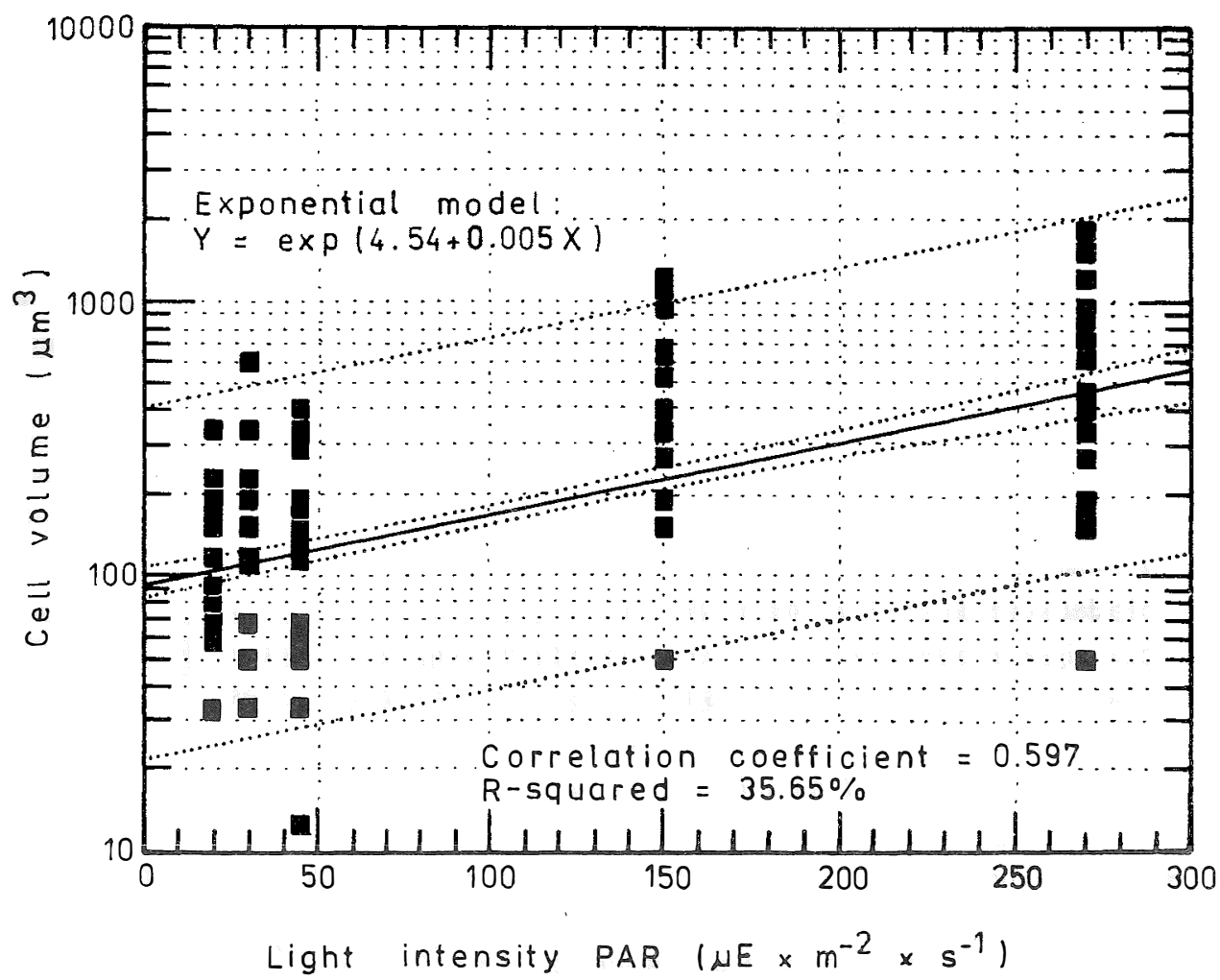

Fig. 10. The plot of regression between light intensity and cell volume of Oocystis parva, together with measured values. Dotted lines represent confidence and prediction limits

\section{DISCUSSION}

The growth cycle of algal species as well as their photosynthetic or enzymatic activities show a strong dependence on salinity changes. The optimum salinity for growth of many planktonic algae was determined (Braarud 1961; Guillard and Mylestad 1970). According to Proskina-Lavrenko (1963), the optimal salinity for a given species is the same as in its natural habitat. Results of the present study show that 3 species only (Species 1, 8, 9) grew best in a salinity typical of the Gulf of Gdańsk, whereas the majority of the algae cultured prefered fresh water. This fact confirms the opinion on the typical freshwater nature of most planktonic green algae (Starmach 1963).

Decreasing salinity brings about a significant decrease in the algal metabolic rate and, in consequence, dwarfish organisms in brackish ecosystems are observed (Remane and Schlieper 1958). The present results conform with this statement. The cell volume of each species tested, except for Oocystis parva, decreased gradually with 
decreasing salinity. The correlation coefficient and $\mathrm{R}^{2}$ values indicated that the salinity fluctuations are responsible for $30 \%$ of the cell volume changes in 6 species, the contribution of salinity variations reaching $64 \%$ in Scenedesmus armatus. Marked differences were found to exist in the cell size before and after cell division. In spote of the high variability of cell volume, the correlation coefficient and $R^{2}$ values show a significant relationship between the cell volume and salinity.

Temperature is doubtless one of the most important factors controlling growth of many algal species. At low temperatures, all biochemical processes proceeed at a slow rate, low temperatures inhibiting the metabolic activity and growth of the organism. On the other hand, high temperatures could result in enzyme inactivation and soluble protein coagulation. However, during evolution, organisms developed certain mechanisms relieving them from strict temperature dependence (Bayliss 1960). In most Chlorococcales, the optimal growth temperature is in the range of $20-30^{\circ} \mathrm{C}$ (Felfoldy 1961; Jankowski 1964). Komárek and Ružička (1969) divided the strains of chlorococcal algae into several groups according to their temperature optima. Following this division, Chlorella vulgaris (Species 1), Scenedesmus armatus (Species 2), and S. acumi natus (Species 3) belong to the high-temperature strains with temperature optima between 30 and $38^{\circ} \mathrm{C}$. Monoraphidium contortum (Species 5) and M. griffithii (Species 6) belong to the mesothermophilic strains with temperature optima of $20-30^{\circ} \mathrm{C}$, whereas Scenedesmus acutus (Species 4), Oocystis submarina (Species 7), and O.parva (Species 8) belong to the low-temperature strains with temperature optima below $20^{\circ} \mathrm{C}$. This classification would place Stichococcus bacillaris (Ulotrichales) among the mesothermophilic algae. To supplement the classification with the results obtained in this study, one can say that the mesothermophilic species do not grow at $10^{\circ} \mathrm{C}$ and below, whereas the low-temperature species tolerate $5^{\circ} \mathrm{C}$ but do not grow at $38^{\circ} \mathrm{C}$.

Temperature affects also the cell size. Species living in cold waters attain greater dimensions than their warmer water relatives. Laboratory experiments demonstrated the cell size to often decrease with increasing temperature. Such a relationship was shown for the diatom Skeletonema costatum (Jorgensen 1968) and the green alga Scenedesmus quadricauda (Komárek and Ružička 1969). In the present study, the correlation between the cell volume and a wide range of temperature was noted in two Scenedesmus species (Species 2 and 3) as well. The largest temperature effect on cell volume was observed in Scenedesmus acuminatus, $42 \%$ of changes in the cell volume being ascribed to temperature.

Algae, particularly the planktonic ones, are able to rapidly and actively adapt to different light conditions. The process involves an increase in the chloroplast pigment content, changes of the pigment ratios, and chloroplast movements within the cell (Steemann Nielsen 1975). When the increasing light intensity limits the cell division rate, the algal biomass increases up to the light saturation of growth. Light intensities saturating the growth of different algal species are generally in the range of 40-100 
$\mu \mathrm{E} / \mathrm{m}^{2}$ s (Chang 1980; Durbin 1974; Paasche 1968). Sorokin and Krauss (1958) examined several green algae and reported that growth of Chlorella vulgaris was saturated at $250 \mathrm{ftc}$ (about $50 \mu \mathrm{E} / \mathrm{m}^{2} \mathrm{~s}$ ). Similar results were obtained in the present study, i.e. 45-120 $\mu \mathrm{E} / \mathrm{m}^{2} \mathrm{~s}$. Most species cultured here showed relatively high light demands. In 6 species, growth was saturated at $120 \mu \mathrm{E} / \mathrm{m}^{2} \mathrm{~s}$. High light intensities inhibit algal growth the relevant literature data ranging within $120-600 \mu \mathrm{E} / \mathrm{m}^{2}$ s. Sorokin and Krauss (1958) found that the values in green algae were between 200 and $600 \mathrm{ftc}\left(120-400 \mu \mathrm{E} / \mathrm{m}^{2} \mathrm{~s}\right)$. Komárek and Ružička (1969), however, demonstrated that growth of Scenedesmus qua. dricauda was saturated at about $600 \mu \mathrm{E} / \mathrm{m}^{2}$. Most species studied here (except for Oocystis submarina) tolerated the highest light intensity used $\left(380 \mu \mathrm{E} / \mathrm{m}^{2} \mathrm{~s}\right)$, but their growth was not so pronounced as that at lower light intensities.

According to Morimura (1959), Overbeck and Stang-Bursche (1966), and Komárek and Ruzička (1969), the size of algal cells increases with increasing light intensity. The results obtained here confirm such a relationship only in five of the species studied. The highest correlation was obtained in Oocystis parva with increasing light intensity being respoonsible for $35 \%$ of the cell size increase.

\section{REFERENCES}

Bayliss $\mathbb{L}$ E E. 1960: Principles of general physiology. Volume Two. Longmans, Green \& Co.

Braarud $\mathbb{T}_{o,}$ 1961: Cultivation of marine organisms as a means of understanding environmental influences on populations. In: Sears, M. (ed.): Oceanography: 271-298.

Chang T.A., 1980: Comparative physiological study of marine diatoms and dinoflagellates in relation to irradiance and cell size. II. J. Phycol., 16: 428-432.

Durbin $\mathbb{E}_{0} G_{0}$, 1974: Studies on the autecology of the marine diatom Thalossiosira nordenskioldii lleve. I. J. Ohycol., 10: 220-225.

Badler Lo, 1979: Recommendation on methods for marine biological studies in the Baltic Sea. Phytoplankton and chlorophyll. BMB Publ. 5, 38 pp.

Felfroldy $\mathbb{L}_{\circ} \mathbb{J}_{\text {Mog }}$ 1961: Effect of temperature on photosynthesis in three unicellular green algal strains. Acta biol. Acad. Sci. Hung, 12: 153Ż159.

Foog G.E. B. Thalse, 1987: Algal cultures and phytoplankton ecology. Univ. Wisconsin Press, 269 pp.

Guillard P.RLLo, 1975: Culture of phytoplankton for feeding marine invertebrates. In: Smith, W.Lo, Chanley, M.H. (eds.): Culture of marine invertebrate animals. Plenum Press: 29-60.

Guillard $\mathbb{R}_{0} \mathbb{R}_{0} \mathbb{T}_{\text {og }}$ S. Myldestad, 1970: Osmotic and ionic requirements of the marine centric diatom Cyclotelle nono. Helgolånder wiss. Meeresunters., 20: 104-110.

Jankowski $A_{0}$, 1964: Algae selection investigations for mass culture purposes. Inst。 Zootechn。Krakoow, 186, $83 \mathrm{pp}$.

Jorgensen $\mathbb{E}_{0} G_{\circ}$ 1968: The adaptation of plankton algae. II. Aspects of the temperature adaptation of Skeletoneme costotusm. Physiol. Planto, 21: 423-427.

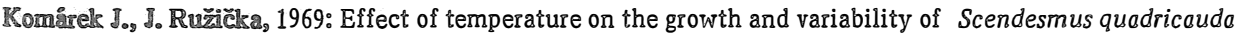
(Turp.) Breb. in: Fott, B. (ed.): Studies in phycology. Publ. House Czech Acad. Sci.: 262-292.

Morimura: Y.o, 1959: Synchronous culture of Chlorello. I. Plant Cell Physiol., 1:49-62.

Overbeck Jos E.M. Stange-Bursche, 1966: Experimentalle Untersuchungen zum Coenobienformwechsel von Scenedesmus quadricauda (Turp.) Breb. Ber。 disch. bot. Ges, 78: 357-372. 
Pasche E.,. 1968: Marine plankton algae grown with light-dark cycles. II. Ditylum brightwellii and Nitzsche turgibula. Physiol. Plant., 21: 66-77.

Plin̊ski M., I. Florczyk, J. Picin̊ska, 1985: Skład i liczebnos̊c̊ fitoplanktonu Zatoki Gdańskiej Właściwej. Stud. Mat. Oceanolog., 46: 23-64.

Proskina-Lavrenko A.I., 1963: Diatomovye vodorosli bentosa Chernogo Mora. Izdat. AN SSSR, Moskva.

Remane A., C. Schlieper, 1958: Die Biologie des Brackwasser. Die Binnengewässer, 22, 348 pp.

Round F.E., 1977: The biology of the algae. Edward Arnold, 278 pp.

Sorokin C., R.W. Krauss, 1958: The effects of light intensity on the growth rates of green algae. Plant Physiol., 33: 109-113.

Starmach K., 1963: Rośliny słodkowodne. Wstęp ogo̊lny i zarys metod badania. PWN Warszawa, 271 pp.

Steemann Nielsen E., 1975: Marine photosynthesis (with special emphasis on the ecological aspects). Elsevier Amsterdam, $141 \mathrm{pp}$.

Author's addresses:

A. Latå̊a, M. Pliński

Institute of Oceanography

Gdańsk University

Al. Piłsudskiego 46

81-378 Gdynia

Poland 